\title{
PENGARUH MODEL PEMBELAJARAN THINK TALK WRITE BERBANTUAN MIND MAPPING TERHADAP KOMPETENSI PENGETAHUAN IPA KELAS IV
}

\author{
Ni Made Dian Pramita Dewi ${ }^{1}$, IB. Gede Surya Abadi ${ }^{2}$, Ni Wayan Suniasih ${ }^{3}$ \\ 1,2,3 Jurusan Pendidikan Guru Sekolah Dasar, Universitas Pendidikan Ganesha, Singaraja \\ e-mail : dewi.made27@undiksha.ac.id ${ }^{1}$,idabagusgedesurya.abadi@undiksha.ac.id ${ }^{2}$, \\ niwayan.suniasih@undiksha.ac.id ${ }^{3}$
}

\begin{abstract}
Abstrak
Tujuan penelitian ini adalah untuk mengetahui pengaruh model pembelajaran think talk write berbantuan mind mapping terhadap kompetensi pengetahuan IPA siswa kelas IV SD Gugus Kompyang Sujana Denpasar Utara tahun ajaran 2017/2018. Jenis penelitian ini adalah eksperimen semu menggunakan desain rancangan kelompok nonequivalent control group design. Populasi penelitian ini adalah seluruh siswa kelas IV SD Gugus Kompyang Sujana Denpasar Utara yang berjumlah 350 orang. Sampel ditentukan dengan teknik random sampling dengan mengacak kelas. Sampel yang didapatkan disetarakan terlebih dahulu menggunakan uji-t polled varians. Penentuan kelompok eksperimen dan kontrol dilakukan dengan cara undian sehingga diperoleh siswa kelas IV SDN 4 Tonja dengan jumlah 42 siswa sebagai kelompok eksperimen dan siswa kelas IV SDN 2 Peguyangan dengan jumlah 47 siswa sebagai kelompok kontrol. Data kompetensi pengetahuan IPA dikumpulkan dengan instrumen berupa tes objektif bentuk pilihan ganda biasa berjumlah 32 butir tes yang telah divalidasi. Hasil perhitungan data gain skor ternormalisasi kompetensi pengetahuan IPA menunjukkan nilai rata - rata kompetensi pengetahuan IPA kelompok eksperimen lebih tinggi dibandingkan rata - rata kompetensi pengetahuan IPA kelompok kontrol $(\bar{X}$ eksperimen $=0,52>\bar{X}$ kontrol $=0,32$ ). Pengujian hipotesis analisis menggunakan uji-t dengan rumus polled varians, diperoleh harga $t_{\text {hitung }}=5,992>t_{\text {tabel }}(\alpha=0,05,87)=2,000$. Hasil penelitian menunjukkan bahwa terdapat pengaruh model pembelajaran think talk write berbantuan mind mapping terhadap kompetensi pengetahuan IPA siswa kelas IV SD Gugus Kompyang Sujana Denpasar Utara tahun ajaran 2017/2018.
\end{abstract}

Kata kunci :Think Talk Write, Mind Mapping, Kompetensi Pengetahuan IPA

\section{Abstract}

The porpuse of this research aimed to know about the effect of think talk write learning model assisted by mind mapping against the natural science competence of $4^{\text {th }}$ grade class elementary scholl of Kompyang Sujana District of North Denpasar in the 2017/2018academic year. This type of research was a quasi-experiment using a nonequivalent control group design. The population of this research were all of the students in the $4^{\text {th }}$ grade of the elementary school in Kompyang Sujana District of North Denpasar containing 350 people. The sample determined by random sampling technique by randomizing the class. The obtained sample was previously equalized using T-test polled variance. Therefore, the sample of this research was the fourth-grade students of SDN 4 Tonja with the total amount of 42 students as the experimental group and the fourth-grade students of SDN 2 Peguyangan containing 47 students as the control group. The knowledge competence data of natural science subject collected by using the instrument in the form of objective test or multiple choice. The test that consisted of 32 items has been validated. The result ofcalculation of "gain" data score showed the average value of science knowledge competence of experimental class students was higher than the average knowledge competence of science students of control class (experimental $=0,52>$ control $=0,32$ ). Hypothesis testing was analyzed using the t-test with the formula "polled variance", and data are prove by the result of tcal $=5.992>\operatorname{ttab}(\alpha=0.05,87)=2,000$. The result of the research shows that the learning model of think talk write assisted by mind mapping affects the students' competence of natural science subject of the fourth-grade in Gugus Kompyang Sujana North Denpasar in the 2017/2018 academic year.

Keyword: mind mapping, think talk write, natural science competence. 


\section{Pendahuluan}

Menghadapi situasi masyarakat yang selalu berubah, idealnya pendidikan harus berorientasi terhadap proses perubahan yang bersifat adaptif dan antisipatif karena pendidikan merupakan hal yang sangat fundamental bagi kehidupan seseorang. Pandangan tentang belajar mendasari kurikulum yang akan dilaksanakan karena pada proses pembelajaran di sekolah dilaksanakan dengan berpedoman pada kurikulum yang berlaku. Menurut Hamalik (2013:16) "kurikulum ialah sejumlah mata ajaran yang harus ditempuh dan dipelajari oleh siswa untuk memperoleh sejumlah pengetahuan". Kurikulum yang berlaku saat ini adalah kurikulum 2013 yang merupakan penyempurnaan dari kurikulum 2006 (KTSP). Salah satu implikasi yang paling menonjol dari kurikulum 2013, utamanya untuk jenjang sekolah dasar/madrasah dilakukan melalui pembelajaran tematik terpadu dari kelas I sampai kelas VI secara bertahap. Pembelajaran tematik terpadu menciptakan pola pembelajaran berbasis pada tema yang terdiri dari beberapa sub tema yang mengintegrasikan beberapa mata pelajaran seperti Bahasa Indonesia, PKn, Matematika, IPA, IPS, Penjaskes dan SBdP. Dengan demikian pembelajaran memberikan makna yang utuh kepada peserta didik seperti tercermin pada tema yang tersedia. Untuk mendukung model tematik terpadu maka digunakan suatu metode pembelajaran pada kurikulum 2013 yaitu pendekatan saintifik (Permendikbud No. 56 Tahun 2013). Esensi pendekatan saintifik dalam proses pembelajaran memadukan penalaran induktif dan deduktif di setiap proses pengalaman belajar, sehingga kegiatan belajar siswa akan sejalan dengan kompetensi yang dikembangkan.

Berdasarkan kegiatan observasi yang telah dilaksanakan pada hari kamis 4 Januari 2018 di SD Gugus Kompyang Sujana, kemampuan peserta didik dalam mengejar target ketercapaian materi yang diberikan masih belum optimal. Dalam pelaksanaannya, siswa masih cenderung menghafal informasi dengan materi pembelajaran yang cukup padat tanpa didukung adanya pendekatan atau strategi pembelajaran yang bervariasi. Hal ini menyebabkan siswa kurang termotivasi dalam belajar dan menyebabkan siswa kurang memahami pelajaran yang diajarkan oleh guru sehingga berdampak pada pencapaian kompetensi pengetahuan siswa. Kondisi tersebut terlihat dari hasil ulangan harian siswa khususnya pada muatan materi IPA yang saat ini masih belum sesuai dengan harapan sekolah dan dalam hal ini memerlukan perhatian yang lebih karena IPA merupakan salah satu mata pelajaran pokok dalam kurikulum pendidikan.

IPA merupakan ilmu yang mempelajari peristiwa-peristiwa yang terjadi di alam, berbagai dimensi ruang dan waktu serta berbagai aktivitas kehidupannya. Oleh karena itu, perlu adanya rancangan pembelajaran yang dapat membuat siswa berpartisipasi aktif menanya, mengkomunikasikan ide-idenya secara aktif dalam diskusi yang akan mempengaruhi hasil belajar belajar siswa. Sejalan dengan pendapat Susanto (2016:93), salah satu faktor yang mempengaruhi hasil belajar adalah guru, meliputi kemampuan guru yang kreatif dalam mendesain model pembelajaran sehingga siswa dapat memahami materi yang diberikan dan mencapai pembelajaran bermakna. Untuk itu strategi guru dalam penggunaan metode ataupun model pembelajaran sangat diperlukan agar proses penyampaian dan transferasi ilmu dapat berjalan seperti yang diharapkan terutama pada muatan materi IPA di sekolah dasar.

Secara teoretis, terdapat rancangan yang disinyalir dapat berpengaruh terhadap kompetensi pengetahuan IPA, yaitu dengan menerapkan model pembelajaran yang inovatif agar situasi pembelajaran menjadi menyenangkan, aktif, dan bermakna bagi siswa. Model pembelajaran yang dapat mendukung proses pembelajaran pada penelitian ini adalah model pembelajaran think talk write. Model pembelajaran think talk write merupakan salah satu tipe pembelajaran yang sejalan dengan pembelajaran kooperatif, menekankan pada kegiatan bekerja sama dalam tugas-tugas terstuktur yang menumbuhkembangkan pemahaman konsep dan komunikasi peserta didik (Shoimin, 2014:212). Model pembelajaran think talk write, dapat memacu siswa agar dapat mengembangkan cara berfikir, menulis dengan lancar dan melatih bahasa sebelum dituliskan.

Agar proses pembelajaran yang dilaksanakan lebih optimal, maka dibutuhkan penggabungan bantuan untuk mengoptimalkan model yang digunakan dalam pembelajaran. 
Penerapan model think talk write berbantuan mind mapping (peta pikiran) pada proses pembelajaran di kelas disinyalir dapat membuat proses pembelajaran terkesan tidak monoton dan menyenangkan sehingga akan mempengaruhi hasil belajar siswa yang selama ini masih kurang. Melalui model think talk write dengan berbantuan mind mapping, materi pelajaran akan terpola secara visual dan grafis yang akhirnya dapat membantu merekam, memperkuat, dan mengingat kembali informasi yang telah dipelajari, Hendrawan (2017:22).

Berdasarkan uraian tersebut, menunjukkan bahwa model pembelajaran sangat penting diterapkan guru dalam mengoptimalkan kompetensi pengetahuan khususnya pada muatan materi IPA. Namun, untuk mengetahui seberapa jauh model pembelajaran dapat mempengaruhi kompetensi pengetahuan IPA, maka dilakukan penelitian yang berjudul "Pengaruh Model Pembelajaran Think Talk Write Berbantuan Mind Mapping Terhadap Kompetensi Pengetahuan IPA Siswa Kelas IV SD Gugus Kompyang Sujana Denpasar Utara Tahun Ajaran 2017/2018"

\section{METODE}

Pelaksanaan penelitian dilakukan di SD Gugus Kompyang Sujana Kecamatan Denpasar Utara. Populasi dari penelitian ini adalah seluruh siswa kelas IV (empat) SD Gugus Kompyang Sujana tahun ajaran 2017/2018, yang terdiri dari 10 kelas dalam 7 sekolah dasar. Jumlah populasi dari penelitian ini adalah 350 orang. Menurut Sugiyono (2015:117) "populasi adalah wilayah generalisasi yang terdiri atas obyek atau subyek yang mempunyai kualitas dan karakteristik tertentu yang ditetapkan oleh peneliti untuk dipelajari dan kemudian ditarik kesimpulan".

Agar nantinya hasil penelitian dapat tergeneralisasi dan mewakili seluruh karakteristik populasi maka diperlukan pemilihan sampel penelitian. Sampel adalah bagian dari jumlah dan karakteristik yang dipilih untuk mewakili seluruh populasi dan diambil dengan menggunakan teknik tertentu. Teknik pengambilan sampel pada penelitian ini adalah random sampling dimana yang dirandom adalah kelasnya, sehingga setiap kelas mendapatkan peluang yang sama untuk menjadi sampel penelitian. Pemilihan sampel penelitian ini tidak dilakukannya pengacakan individu melainkan hanya pengacakan kelas,karena tidak bisa mengubah kelas yang telah terbentuk sebelumnya dan kelas dipilih sebagaimana telah terbentuk tanpa campur tangan peneliti dan tidak dilakukannya pengacakan individu. Sehingga kemungkinan pengaruhpengaruh dari keadaan siswa mengetahui dirinya dilibatkan dalam eksperimen dapat dikurangi sehingga penelitian ini benar-benar menggambarkan pengaruh perlakuan yang diberikan.

Untuk mendapatkan dua kelas yang dijadikan kelompok eksperimen dan kelompok kontrol maka dilakukan pada kelas yang sudah terbentuk sehingga terpilih dua kelas yang representatif untuk dijadikan sampel penelitian. Setelah dua kelas terpilih melalui pengundian, maka dilakukan uji kesetaraan untuk mengetahui tingkat kesetaraan kedua kelas yang dijadikan kelompok eksperimen dan kelompok kontrol dengan menggunakan nilai hasil kompetensi pengetahuan siswa melalui pre-test. Untuk penyetaraan sampel yang terpilih, nilai atau skor dari hasil pre-test kedua kelompok dianalisis menggunakan uji-t. Sebelum uji kesetaraan menggunakan uji-t, maka data hasil pre-test diuji melalui uji prasyarat normalitas dan homogenitas. Jika data pre-test yang diperoleh sudah memenuhi prasyarat uji normalitas dan homogenitas maka dianalisis menggunakan uji-t. Setelah kedua sampel dinyatakan setara, peneliti melakukan pengundian lagi dari 2 sampel untuk memilih nama sekolah yang digunakan sebagai kelompok kontrol dan kelompok eksperimen. Sampel dalam penelitian ini adalah siswa kelas IVB SDN 4 Tonja dengan jumlah 42 siswa sebagai kelompok eksperimen yang dibelajarkan menggunakan model pembelajaran think talk write berbantuan mind mapping dan siswa kelas IV SDN 2 Peguyangan dengan jumlah 47 siswa sebagai kelompok kontrol yang dibelajarkan dengan pembelajaran seperti biasa berlangsung.

Waktu penelitian terkait dengan penelitian ini dilaksanakan selama 1 bulan mulai maret sampai dengan April 2018, perlakuan sebanyak 6 kali di kelompok eksperimen dan membandingkan sebanyak 6 kali pertemuan di tema yang sama pada kelompok kontrol. 
Jumlah perlakuan yang diberikan telah disesuaikan dengan jam pelajaran terkait materi dalam penelitian ini yang telah diatur dalam kurikulum yang berlaku di sekolah dasar.

Jenis penelitian yang dilakukan dalam penelitian ini adalah penelitian kuantitatif dengan jenis eksperimental yaitu quasi eksperiment (eksperimen semu). Desain ini memiliki kelompok kontrol, tetapi tidak bisa sepenuhnya mengontrol variabel - variabel luar yang mempengaruhi pelaksanaan eksperimen. Hal ini dikarenakan kemampuan peneliti dalam mengamati perilaku siswa sangat terbatas terutama ketika siswa berada di luar sekolah (rumah), peneliti juga tidak memiliki kemampuan untuk mengetahui persepsi siswa terhadap perlakuan secara pasti.

Rancangan pada penelitian eksperimen yang digunakan adalah "Nonequivalent control group design". Pada desain ini, baik kelompok eksperimen maupun kelompok kontrol dibandingkan. Pre-test diberikan untuk kelompok kontrol dan kelompok eksperimen. Setelah itu penelitii memberikan perlakuan, yaitu dengan memberikan model think talk write berbantuan mind mapping kepada kelompok eksperimen dan membandingkan dengan kelompok kontrol melalui pembelajaran yang biasa diterapkan di kelompok kontrol. Kemudian setelah diberikan perlakuan, dilakukan post-test untuk mengetahui data kompetensii pengetahuan IPA. Untuk pengujian hipotesis yang diajukan, data yang dianalisis adalah data gain skor kompetensi pengetahuan IPA yang telah ternormalisasi, dimana instrumen yang digunakan telah melalui validasi instrumen yaitu uji validitas isi, uji validitas butir, uji daya beda, indeks kesukaran dan uji reliabilitas. Sehingga berdasarkan validasi instrumen yang telah dilakukan diperoleh 32 butir tes yang layak dipergunakan dalam pengumpulan data.

Dalam menganalisis data digunakan metode analisis statistik inferensial. Pada statistik inferensial data yang dianalisis adalah gain skor yang ternormalisasi dari hasil pre test dan post test. Teknik analisis data yang digunakan untuk menguji hipotesis dalam penelitian ini yaitu menggunakan uji-t dengan rumus polled varians. Uji-t ini digunakan apabila telah memenuhi uji prasyarat yaitu uji normalitas sebaran data dan homogenitas varians. Uji normalitas dilakukan untuk mengetahui apakah sebaran frekuensi skor pada setiap variabel berdistribusi normal atau tidak. Uji normalitas sebaran data yang digunakan pada penelitian ini menggunakan Kolmogorov-Smirnov. Uji Kolmogorov-Smirnov dapat digunakan untuk sampel besar maupun sampel kecil dan berita data interval. Kriteria pada uji normalitas kolmogorov adalah signifikansi uji pada nilai | Ft - Fs | terbesar dibandingkan nilai tabel kolmogorov smirnov. Pada taraf signifikansi 5\%, dan perbandingan jumlah siswa, apabila nilai | Ft - Fs | terbesar kurang dari nilai tabel kolmogorov smirnov, maka $\mathrm{H}_{\circ}$ ditolak dan $\mathrm{H}_{\mathrm{a}}$ diterima. Uji homogenitas varians dilakukan untuk mencari tingkat homogen (kesamaan) antara dua pihak yang diambil dari kelompok-kelompok terpisah satu populasi yaitu kelompok eksperimen dan kelompok kontrol. Uji homogenitas varians untuk kedua kelompok digunakan uji F. Dengan kriteria pengujian pada taraf signifikansi $5 \%$ dengan derajat kebebasan (dk) untuk $n_{\text {pembilang }}-1$ dan derajat kebebasan (dk) untuk $n_{\text {penyebut }}-1$. $F_{\text {hitung }} \geq F_{\text {tabel }}$ maka sampel homogen.

Data yang telah memenuhi uji prasyarat uji normalitas dan uji homogenitas datanya, dilanjutkan dengan pengujian hipotesis. Hipotesis yang diuji dalam penelitian ini adalah $\mathrm{H}_{\circ}$ yaitu tidak terdapat pengaruh model pembelajaran think talk write berbantuan mind mapping terhadap kompetensi pengetahuan IPA siswa kelas IV SD Gugus Kompyang Sujana Denpasar Utara tahun ajaran 2017/2018. Kriteria pengujian ini dengan taraf signifikansi 5\% yang mengkomparasikan $t_{\text {hitung }}$ dengan $t_{\text {tabel }}$. Apabila $t_{\text {hitung }}>t_{\text {tabel }}$ maka terdapat pengaruh antara kedua variabel atau sampel ( $\mathrm{H}_{0}$ ditolak) (Sugiyono, 2013:138). Adapun rumus uji-t yang digunakan adalah sebagai berikut.

$$
\frac{\bar{x}_{1}-\bar{x}_{2}}{\sqrt{\frac{\left(n_{1}-1\right) s_{1}^{3}+\left(n_{2}-1\right) s_{2}^{3}}{n_{1}+n_{2}-2}\left(\frac{1}{n_{1}}+\frac{1}{n_{2}}\right)}}
$$




\section{HASIL DAN PEMBAHASAN}

Data kompetensi pengetahuan IPA diperoleh dari hasil gain skor yang telah ternormalisasi yaitu selisih data posttest dan pretest yang diberikan. Kelompok eksperimen yang digunakan dalam penelitian ini adalah kelas IV SDN 4 dengan jumlah siswa 42 orang, sedangkan kelompok kontrol adalah kelas IV SDN 2 Peguyangan dengan jumlah siswa 47 orang. Teknik pengumpulan data dalam penelitian ini menggunakan metode tes. Tes yang akan digunakan untuk mengukur hasil kompetensi pengetahuan IPA siswa berupa tes objektif dalam bentuk pilihan ganda biasa, dilakukan pengujian instrumen yaitu uji validitas, reliabilitas, daya beda dan indeks kesukaran. Rancangan penelitian yang digunakan dalam penelitian ini adalah nonequivalent control group design yang dianalisis menggunakan uji-t apabila telah melalui uji prasyarat normalitas dan homogenitas. Deskripsi data kompetensi pengetahuan IPA siswa melalui tabel data kompetensi pengetahuan IPA siswa, tabel distribusi frekuensi dan histogram.

Nilai mean atau rerata kompetensi pengetahuan IPA siswa dari data gain skor pada kelompok eksperimen yaitu $\bar{X}=0,52$ dengan varians 0,03 dan standar deviasi $(\mathrm{s}=0,17)$. Adapun histogram yang dapat menggambarkan data kelompok eksperimen disajikan sebagai berikut..

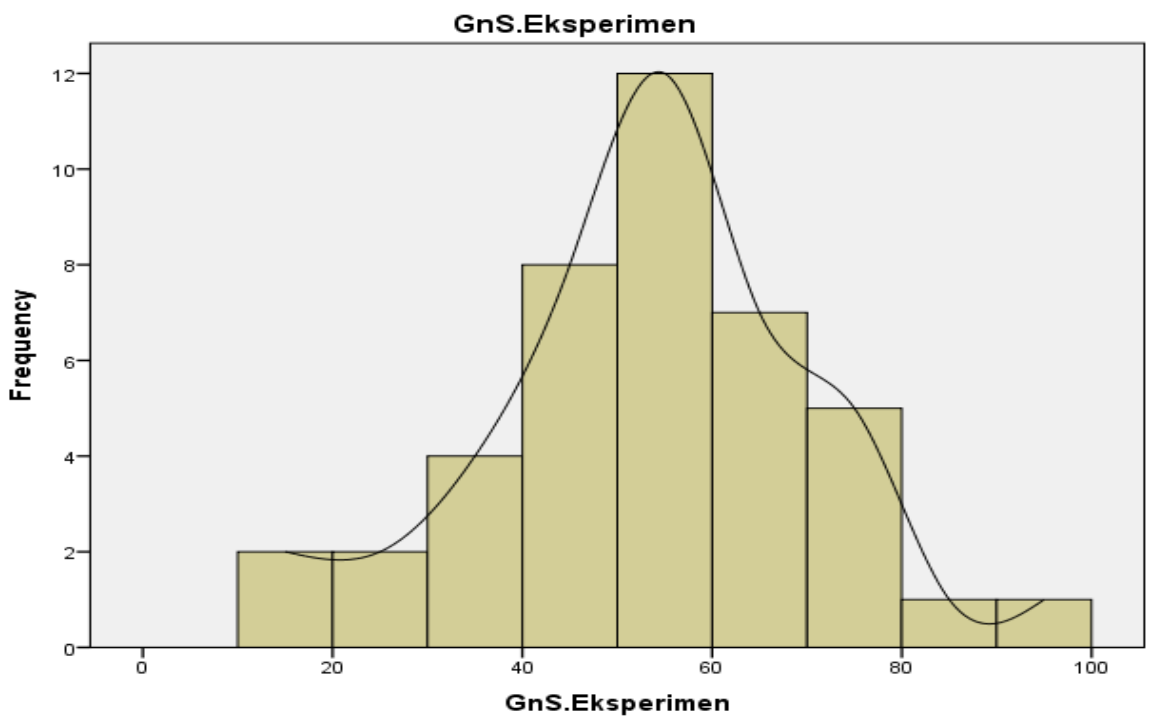

Sedangkan nilai mean atau rerata siswa pada kelompok kontrol, yaitu $\bar{X}=0,32$ dengan varians 0,02 dan standar deviasi $(s=0,12)$. Adapun gambaran data kelompok kontrol adalah sebagai berikut.

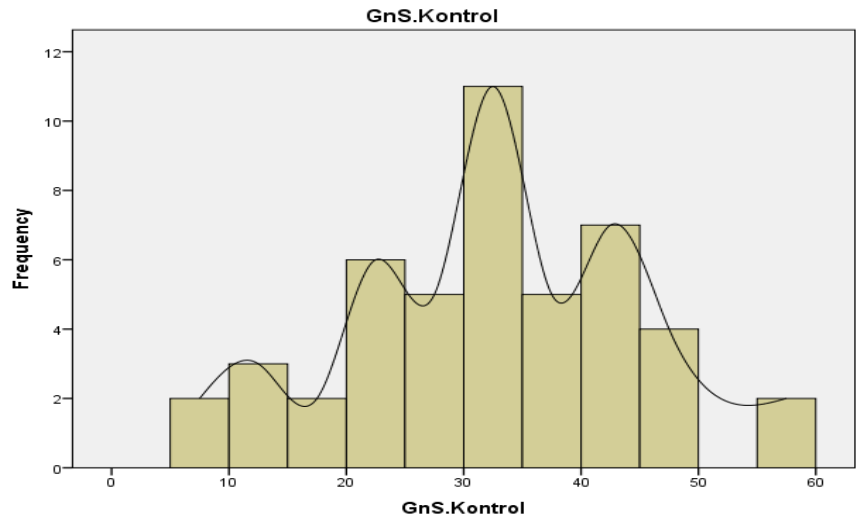


Perhitungan analisis data hasil penelitian yang diperoleh menunjukkan bahwa hasil kompetensi IPA kelompok eksperimen yakni siswa yang mengikuti pembelajaran menggunakan model think talk write berbantuan mind mapping memiliki nilai mean lebih tinggi daripada kelompok kontrol yaitu $\bar{X}=0,52>\bar{X}=0,32$.

Berdasarkan hasil perhitungan rata-rata pada kedua kelompok, maka dapat dinyatakan bahwa rata-rata kelompok eksperimen berbeda dengan rata-rata kelompok kontrol. Selanjutnya dilakukan pengujian hipotesis dengan melalui pengujian asumsi melalui uji prasyarat yang dilakukan terlebih dahulu sebelum uji hipotesis menggunakan uji-t. Uji prasyarat tersebut meliputi uji normalitas dan uji homogenitas varians diuraikan berikut ini. Uji normalitas sebaran data yang digunakan pada penelitian ini menggunakan kolmogorov-smirnov. Uji kolmogorovsmirnov dapat digunakan untuk sampel besar maupun sampel kecil dan berskala data interval. Kriteria pada uji normalitas kolmogorov adalah signifikansi uji pada nilai | Ft - Fs | terbesar dibandingkan nilai tabel kolmogorov smirnov. Pada taraf signifikansi 5\%, dan jumlah siswa, apabila nilai | Ft - Fs | terbesar kurang dari nilai tabel kolmogorov smirnov, maka $\mathrm{H}_{0}$ ditolak dan $\mathrm{H}_{\mathrm{a}}$ diterima.

Berdasarkan hasil uji normalitas kelompok eksperimen, diperoleh nilai | Ft - Fs | terbesar $=0,103$ kemudian nilai tersebut dibandingkan dengan nilai tabel kolmogorov-smirnov dengan taraf signifikan $5 \%$ dan $n=42$, sehingga diperoleh nilai tabel pada kolmogorov $=0,210$. Hal ini menunjukkan bahwa nilai | Ft - Fs | terbesar < nilai tabel kolmogorov dengan taraf signifikansi $5 \%$ dan $n=42$ berarti data hasil hasil kompetensi pengetahuan IPA kelompok eksperimen berdistribusi normal. Berdasarkan hasil uji normalitas kelompok kontrol, diperoleh nilai | Ft - Fs | terbesar $=0,073$ kemudian nilai tersebut dibandingkan dengan nilai tabel kolmogorov-smirnov dengan taraf signifikan $5 \%$ dan $n=47$, sehingga diperoleh nilai tabel pada kolmogorov $=0,198$. Hal ini menunjukkan bahwa nilai | Ft - Fs | terbesar< nilai tabel kolmogorov dengan taraf signifikansi $5 \%$ dan $n=47$ hal ini berarti data hasil hasil kompetensi pengetahuan IPA kelompok kontrol berdistribusi normal.

Pengujian homogenitas varians antar kelompok dimaksudkan untuk meyakinkan bahwa perbedaan yang diperoleh uji-t benar - benar berasal dari perbedaan antar kelompok bukan disebabkan oleh perbedaan di dalam kelompok. Uji homogenitas varians yang dilakukan dalam penelitian ini menggunakan uji-F dari Havley. Dari hasil analisis, varians dari kelompok eksperimen $=0,03$ dan varaians dari kelompok kontrol $=0,02$ sehingga diperoleh $F_{\text {hitung }}=1,50$ dan $F_{\text {tabel }}=1,65$. Hal ini berarti $F_{\text {hitung }}<F_{\text {tabel }}$, sehingga data kedua kelompok memiliki varians yang homogen. Berdasarkan hasil uji prasyarat yang terdiri dari uji normalitas dan uji homogenitas varians, disimpulkan bahwa data kedua kelompok sampel ialah berdistribusi normal dan memiliki varians yang homogen. Dengan demikian, uji hipotesis menggunakan uji-t dapat dilakukan.

Hipotesis yang diuji dalam penelitian ini adalah Ho yang berbunyi tidak terdapat pengaruh model pembelajaran think talk write berbantuan mind mapping terhadap kompetensi pengetahuan IPA siswa kelas IV SD Gugus Kompyang Sujana Denpasar Utara tahun ajaran 2017/2018. Hasil uji prasyarat yang meliputi uji normalitas dan homogenitas varians yang dilakukan dalam penelitian ini diperoleh kedua kelompok sampel berdistribusi normal dan memiliki varians yang homogen. Analisis statistik yang digunakan untuk menguji hipotesis penelitian ini adalah uji-t dengan polled varians. Berdasarkan hasil perhitungan uji-t, diperoleh $\mathrm{t}_{\text {hitung }}=5,992$ dan untuk taraf signifikansi $5 \%$ dengan $\mathrm{dk}=(42+47-2)=87$ diperoleh $\mathrm{t}_{\text {tabel }}=$ 2,000. Dengan demikian, nilai $t_{\text {hitung }}>t_{\text {tabel }}$ yakni 5,992 $>2,000$ sehingga $H_{0}$ ditolak.

Perhitungan selengkapnya tertera pada hasil rekapitulasi hasil analisis uji-t kelompok sampel penelitian yang disajikan dalam tabel 1 . berikut ini. 
Tabel 1. Rekapitulasi Hasil Analisis Uji-t Kelompok Sampel Penelitian

\begin{tabular}{ccccccccc}
\hline No & $\begin{array}{c}\text { Kelompok } \\
\text { Sampel }\end{array}$ & $\mathbf{N}$ & Dk & $\begin{array}{c}\text { Rata-Rata } \\
\text { Gain Skor }\end{array}$ & $\boldsymbol{S}^{2}$ & $\boldsymbol{t}_{\text {hitung }}$ & $\boldsymbol{t}_{\text {tabel }}$ & Keterangan \\
\hline 1. & Eksperimen & 42 & & 0,52 & 0,03 & & 2,000 & \\
2. & Kontrol & 47 & 87 & 0,32 & 0,02 & 5,992 & & $H_{o}$ ditolak \\
\hline
\end{tabular}

Berdasarkan uji hipotesis diperoleh $t_{\text {hitnung }}=5,992$ sedangkan pada taraf signifikansi $5 \%$ dan $d k=87$ diperoleh nilai $t_{\text {tabel }}=2,000$ sehingga $t_{\text {hitung }}=5,992>t_{\text {tabel }}=2,000$. Dengan demikian, hipotesis nol $(\mathrm{Ho})$ ditolak. Hal ini berarti terdapat pengaruh model pembelajaran think talk write berbantuan mind mapping terhadap kompetensi pengetahuan IPA siswa kelas IV di SD Gugus Kompyang Sujana pada tema daerah tempat tinggalku. Perolehan hasil perhitungan analisis data yang dilakukan menunjukkan bahwa nilai rerata siswa yang mengikuti pembelajaran menggunakan model pembelajaran think talk write berbantuan mind mapping $(\bar{X}$ gain skor $=0,52)$ dan siswa pada kelompok kontrol ( $\bar{X}$ gain skor $=0,32$ ) memiliki perbedaan sebesar 0,208. Dengan demikian, model pembelajaran think talk write berbantuan mind mapping berpengaruh terhadap kompetensi pengetahuan IPA siswa kelas IV di SD Gugus Kompyang Sujana.

Berdasarkan hasil temuan tersebut, dapat dinyatakan kedua kelompok sampel penelitian yang memiliki kemampuan setara, setelah diberikan perlakuan berupa pembelajaran dengan menggunakan model pembelajaran think talk write berbantuan mind mapping dan mengikuti pembelajaran menggunakan pendekatan saintifik diperoleh hasil kompetensi pengetahuan yang berbeda. Hal ini dapat dilihat juga dari rerata $(\bar{X})$ siswa yang mengikuti pembelajaran menggunakan model pembelajaran think talk write berbantuan mind mapping lebih tinggi dibandingkan dengan rerata $(\bar{X})$ siswa pada kelompok kontrol. Perbedaan hasil kompetensi pengetahuan IPA dengan perolehan nilai rerata yang lebih tinggi pada kelompok eksperimen dibandingkan kelompok kontrol disebabkan oleh perlakuan berupa model pembelajaran think talk write berbantuan mind mapping dalam muatan materi IPA diberikan pada kelompok eksperimen.

Pada kelompok eksperimen, kegiatan pembelajaran dalam muatan materi IPA menggunakan model pembelajaran think talk write berbantuan mind mapping berjalan dengan optimal dan kondusif. Hal ini disebabkan model pembelajaran think talk write berbantuan mind mapping merupakan suatu inovasi pembelajaran sangat mengintensifkan kegiatan belajar dalam tiga tahapan. Selama kegiatan pembelajaran siswa lebih aktif karena kegiatan pembelajaran menggunakan model pembelajaran think talk write berbantuan mind mapping yang menciptakan suasana belajar bermakna karena siswa dapat mengkontruksi pengetahuannya sendiri pada tahap think. Dilanjutkan pada tahap talk, siswa berkolaborasi menambah ide-ide pengetahuan bersama kelompoknya. Siswa dibebaskan mencari aternatif jawaban sehingga memberikan kegembiraan melalui kegiatan interaksi terhadap lingkungan belajarnya. Pada tahap akhir yaitu write, siswa mendapatkan inovasi mencatat baru berupa mind mapping. Kreatifitas siswa terbentuk secara individu dengan meringkas materi pembelajaran yang telah didapatkan melalui tahap write dengan mind mapping. Berdasarkan hal tersebut, pembelajaran dengan model pembelajaran think talk write berbantuan mind mapping dalam kegiatan pembelajaran yang meliputi kiat - kiat, petunjuk, strategi, dan seluruh proses belajar yang dapat mempertajam daya ingat, serta membuat belajar sebagai suatu proses yang menyenangkan, bermanfaat, dan bermakna. Dengan demikian, siswa lebih memahami materi yang diberikan sekaligus mampu mengaplikasikan dalam kehidupan sehari - hari.

Berbeda pada kelompok kontrol, kegiatan pembelajaran cenderung berpusat pada guru, siswa kurang aktif dalam mengikuti proses pembelajaran. Hal ini disebabkan siswa yang kurang mampu mengaitkan antar materi pada muatan materi IPA dan kesulitan mengikuti setiap langkah pembelajaran yang perlu diberikan bimbingan lebih khusus. 
Pembelajaran menggunakan model pembelajaran think talk write berbantuan mind mapping pada muatan materi IPA memberikan kesempatan yang lebih luas kepada siswa untuk mengonstruksikan pengetahuannya melalui berbagai kegiatan bermakna dan teratur yang tentunya menggembirakan bagi siswa pada setiap langkah pembelajarannya.

Dengan demikian, perbedaan hasil kompetensi pengetahuan IPA dapat terlihat dari langkah pembelajaran yang dilakukan pada kedua kelompok tersebut, hasil analisis uji hipotesis, dan nilai rerata kelompok siswa yang mengikutii pembelajaran menggunakan model pembelajaran think talk write berbantuan mind mapping dengan siswa yang mengikuti pembelajaran seperti biasanya pada kelompok kontrol.

Hasil temuan pada penelitian ini memiliki persamaan dengan penelitian sebelumnya yang relevan dan memperkuat hasil penelitian yang diperoleh, Hasil penelitian ini akan mendukung hasil penelitian yang diajukan oleh Deimia Dewi (2013) yang mengungkapkan bahwa kelebihan dari model think talk write adalah dengan model pembelajaran think talk write dalam pembelajaran menunjang munculnya pembelajaran aktif, kreatif, efektif, dan menyenangkan karena melatih siswa untuk bekerja secara kelompok, melatih keharmonisan dalam hidup bersama atas dasar saling menghargai. Begitu pula dengan berbantuan mind mapping, Malikhah (2016) mengungkapkan bahwa pembelajaran menggunakan mind mapping membantu peserta didik untuk dapat mengikuti kegiatan pembelajaran dengan rasa yang menyenangkan sehingga proses pembelajaran menjadi berkesan.

Berdasarkan uraian tersebut, pembelajaran menggunakan model pembelajaran think talk write berbantuan mind mapping pada muatan materi IPA pada penelitian ini memiliki keunggulan yakni dapat mengoptimalkan kemampuan berpikir dan komunikasi lisan maupun tertulis siswa dalam mengonstruksi pengetahuan sendiri melalui serangkaian usaha berinteraksi dengan lingkungan belajar yang menggembirakan berdasarkan pada komponen pengalaman belajar $5 \mathrm{M}$ didukung oleh peranan guru dalam pemberian pemantapan/pengulangan materi yang dibuktikan dengan perbandingan rata-rata gain skor kompetensi pengetahuan IPA siswa. Dimana, rata-rata nilai kelas eksperimen lebih tinggi dibandingkan nilai rata-rata pada kelas kontrol.

\section{SIMPULAN DAN SARAN}

Berdasarkan hasil pembahasan dan analisis dapat disimpulkan bahwa model pembelajaran think talk write berbantuan mind mapping berpengaruh terhadap kompetensi pengetahuan IPA siswa kelas IV di SD Gugus Kompyang Sujana Denpasar Utara tahun ajaran 2017/2018. Hal ini dibuktikan dengan analisis uji t diperoleh $t_{\text {hitung }}=5,992$ sedangkan pada taraf signifikansi $5 \%$ dan $\mathrm{dk}=87$ diperoleh nilai $t_{\text {tabel }}=2,000$. Karena $t_{\text {hitung }}=5,992>t_{\text {tabel }}=2,000$, serta rerata gain skor kompetensi pengetahuan IPA kelompok eksperimen $\bar{X}=0,52>\bar{X}=0,32$ rerata gain skor kompetensi pengetahuan IPA kelompok kontrol.

Berdasarkan hasil penelitian ini, maka dapat diajukan beberapa saran sebagai tindak lanjut dari penelitian ini. Saran ini diajukan kepada berbagai kalangan sebagai berikut.

1)Guru agar mencoba menerapkan model pembelajaran think talk write berbantuan mind mapping secara lebih lanjut untuk dapat mengoptimalkan kompetensi pengetahuan siswa dan meningkatkan kualitas pembelajaran sesuai dengan harapan, 2) kepala sekolah supaya merekomendasikan model pembelajaran think talk write berbantuan mind mapping sebagai alternatif perbaikan kualitas pembelajaran dan membantu dalam mencapai tujuan pembelajaran yang diharapakan, 3) peneliti lain yang mencoba untuk melanjutkan penelitian ini agar nantinya dapat menambah khasanah keilmuan dalam penelitian ini sehingga menjadi penelitian yang lebih sempurna. 


\section{DAFTAR RUJUKAN}

Agung, A.A Gede. 2014. Metodologi Penelitian Pendidikan. Malang: Aditya Media Publishing.

Agung, A.A Gede. 2016. Statistika Dasar Untuk Pendidikan. Yogyakarta: Deepublish.

Arsyad, Azhar. 2011. Media Pembelajaran. Jakarta: Raja Grafindo Persada.

Arikunto, Suharsimi. 2013. Dasar-dasar Evaluasi Pendidikan. Jakarta: Bumi Aksara.

Ayu Deimia Dewi, Ni Made. 2013. Pengaruh Model Pembelajaran Think-Talk-Write Terhadap Hasil Belajar Ipa Siswa Kelas V Semester II Sd Gugus XV Kecamatan Buleleng.Skripsi(tidak diterbitkan). Jurusan Pendidikan Guru Sekolah Dasar FIP Undiksha

Budimanjaya, Andi. 2015. 95 Strategi Mengajar Multiple Intelligences. Jakarta:Kharisma Putra Utama.

Cahyono,Tri. 2015. Statistik Uji Normalitas. Purwokerto:Yasamas.

Dantes, Nyoman. 2014. Desain Eksperimen dan Analisis Data. Yogyakarta: ANDI.

Hamalik, Oemar. 2013. Kurikulum dan Pembelajaran. Jakarta: Bumi Aksara.

Harmianto, Sri. 2015.Model-Model Pembelajaran Inovatif dan Efektif. Bandung: Alfabeta.

Hendrawan, Gede. 2017. Pengaruh Model Pembelajaran Savi Berbasis Mind Mapping Terhadap Motivasi Belajar Ips Di SD. Skripsi(tidak diterbitkan). Jurusan Pendidikan Guru Sekolah Dasar FIP Undiksha.

Huda, Miftahul. 2013. Model-model Pengajaran dan Pembelajaran. Yogyakarta:Pustaka Pelajar.

Kemendikbud . 2014. Salinan Lampiran Peraturan Menteri Pendidikan dan Republik Indonesia Nomor 103 Tahun 2014 Tentang Pembelajaran pada Pendidikan Dasar dan Pendidikan. Jakarta: Kementrian Pendidikan dan Kebudayaan.

Kemendikbud . 2014. Salinan Lampiran Peraturan Menteri Pendidikan dan Republik Indonesia Nomor 104 Tahun 2014 Tentang Pembelajaran pada Pendidikan Dasar dan Pendidikan. Jakarta: Kementrian Pendidikan dan Kebudayaan.

Kosasih.2014.Strategi Belajar dan Pembelajaran Implementasi Kurikulum 2013. Bandung:Yrama Widya.

Kurniasih, Imas. 2014. Sukses Mengimplementasikan Kurikulum 2013. Jakarta: Kata Pena.

Kurniasih, Berlin. 2016. Ragam pengembangan Model Pembelajaran Untuk meningkatkan Profesionalitas guru. Jakarta:Kata Pena.

Kunandar. 2015. Penilaian Autentik (Penilaian Hasil Belajar Peserta Didik Berdasarkan Kurikulum 2013). Jakarta: Raja Grafindo Persada.

Malikhah, Siti.2016. “Eksperimentasi Model Pembelajaran Think-Talk-Write Dengan Mind Mapping Pada Materi Persamaan Garis Lurus Ditinjau Dari Kreativitas Belajar 
Matematika Peserta Didik Kelas Viii Smp Negeri Di Kabupaten Kudus Tahun Pelajaran 2015/2016". Prodi Magester Pendidikan Matematika UNS, Volume 4, Nomor 8 (hlm.--)

Made Lestari, Gst Ayu. 2017. "Pengaruh Model Pembelajaran Inkuiri Terbimbing Berbantuan Mind Mapping Terhadap Pemahaman Konsep IPA Siswa" ". Jurusan Pendidikan Guru Sekolah Dasar FIP Undiksha, Volume 5,Nomor 3(hlm.--).

Ngalimun. 2016. Strategi dan Model Pembelajaran. Yogyakarta: Aswaja pressindo.

Prastowo, Andi. 2015. Menyusun Rencana Pelaksanaan Pembelajaran (RPP) Tematik Terpadu. Jakarta: Prenadamedia Group.

Ririn Sintya Dewi, Ni Putu. 2017. Penelitian "Pengaruh Model Pembelajaran Kooperatif Tipe Think Pair Share Berbantuan Mind Mapping Terhadap Kompetensi Pengetahuan Ipa Siswa Kelas V Sd Gugus Kompyang Sujana Denpasar Utara”. Jurusan Pendidikan Guru Sekolah Dasar FIP Undiksha, Volume 5,Nomor 2(hlm.--).

Risa Matallia,Ni Km. 2013."Pengaruh Strategi Pembelajaran Think Talk Write (Ttw) Berbantuan Media Lingkungan Terhadap Hasil Belajar Ipa Siswa Kelas V Sd Negeri Ularan." Jurusan Pendidikan Guru Sekolah Dasar FIP Undiksha, Volume -,Nomor -.

Samatowa usman. 2016. Pembelajaran IPA d Sekolah Dasar. Jakarta: PT Indeks.

Sari Rahma Candra. 2014. Penelitian "Pengaruh Model Pembelajaran Tipe Think Talk Write Dan Gender Terhadap Kemampuan Komunikasi MatematisSiswa Kelas Viii Smpn 12 Padang". Jurusan Matematika FMIPA UNP, Volume 3, Nomor 2 (hlm.--)

Setyosari, H.Punaji. 2015. Metode Penelitian Pendidikan \& Pengembangan. Jakarta: Kencana.

Shoimin, Aris. 2014. 68 Model Pembelajaran Inovatif dalam Kurikulum 2013. Yogyakarta: AR-RUZZ MEDIA. 